\title{
Aikuiskoulutuksen voimavarat ja niiden käyttö
}

\author{
Koistinen, Seppo. 1985. Aikuiskasvatuksen voimavarat ja niiden käyttö. Aikuiskasva- \\ tus, 5, 1, 15-21. - Artikkeli on katsaus opetusministeriön ja aikuiskoulutuksen joh- \\ toryhmän toimeksiannosta suoritettuun selvitykseen maamme aikuiskoulutuksen voi- \\ mavaroista ja niiden käytöstä. Selvitys valmistui vuoden 1984 lopulla.
}

\section{Aikuiskoulutuksen voima- varojen selvittäminen}

Selvitystyö käynnistettiin yhtenä 'Aikuiskoulutuksen kehittämisen yleissuunnitelmassa' mainituista selvitystehtävistä. Muut selvitystehtävät koskivat aikuiskoulutuksen kustannusvastuuta ja kustannusten jakoa sekä peruskoulun ja lukion suorittamista aikuisiässä. Voimavaraselvityksen toimeksianto käsitti sen määrärahojen selvittämisen, joka on kohdennettu valtion tulo- ja menoarviossa aikuiskoulutukseen, aikuiskoulutuksen henkilöstöön, tiloihin ja välineisiin. Tehtävän suorittamiseen sisältyi voimavarojen määrällinen inventointi, käyttöasteen arviointi sekä voimavarojen käyttöön liittyvien ongelmien ja esteiden kartoitus. Selvitysajankohdaksi valittiin vuosi 1980 , joskin valtion tulo-ja menoarvion aikuiskoulutusmäärahat arvioitiin vuosilta 1981 ja 1982.

Selvitystehtävän lähtökohtana oli se, että aikuiskoulutuksen voimavaroihin liittyvä kokonaisvaltainen selvitys puuttui. Tosin oli olemassa joitain suppeita erillisselvityksiä, mutta niiden kattavuus oli vähäinen. Aikuiskoulutuskomitean perustyöllä (komiteanmietinnöt 1971: A 29 ja 1975: 28) on ollut merkitystä myös voimavaroja koskevassa selvitystyössä.

Selvityksen kohteeksi oli tarkoitus saada kaikki sellaiset voimavarat, joiden arvioitiin olevan aikuiskoulutuksen käytössä. Ulkopuolelle selvityksen jätettiin tietoisesti eräitä aikuiskoulutukseen osittain kuuluvia lohkoja. Näistä arvioitiin mahdottomaksi saada riittävän luotettavalla tavalla erotetuksi aikuiskoulutukseen kuuluvia voimavaroja (mm. oppisopimuskoulutus, musiikkioppilaitokset sekä sotilaskoulutus). Osan aikuiskoulutuksen voimavaroista arvioitiin jäävän selvityksen ulkopuo- lelle käytettävissä olevan tilastoaineiston puutteellisuuden vuoksi. Selvityksen piiriin arvioitiin saatavan kuitenkin niin suuri osa aikuiskoulutuksen käytössä olevista voimavaroista, että olisi mahdollista tehdä niiden määrään ja laatuun liittyviä johtopäätöksiä.

Selvitys suoritettiin henkilöstön, tilojen ja välineiden määrää ja laatua sekä voimavarojen käytön ongelmia ja esteitä koskevana kyselynä eri aikuiskoulutusyksiköille. Tiedot selvityksen kohteena olevista asioista pyydettiin kaikkiaan 726:lta aikuiskoulutusyksiköltä (mm. ammatilliset oppilaitokset, ammatilliset kurssikeskukset, iltaoppikoulut ja oppikoulujen iltalinjat, kesäyliopistot, kansalais- ja työväenopistot, kansanopistot, opintokeskukset, urheiluopistot, kirjeopistot, yksityiset ja julkisen vallan henkilöstökoulutuslaitokset sekä yksityiset aikuiskoulutuslaitokset). Kaikille ministeriöille ja niiden alaisille koulutuslaitoksille osoitettiin samalla tiedustelu niiden aikuiskoulutukseen käyttämien määrärahojen suuruudesta ja luonteesta.

Selvitystehtävä osoittautui alueeltaan laajaksi ja vaikeaksi. Aikuiskoulutusyksiköille toimitetusta kyselylomakkeesta tuli pitkä ja yksityiskohtainen. Tästä huolimatta vastausprosentti kohosi korkeaksi eli 79\%:ksi. Vastausprosentti vaihteli jossain määrin aikuiskoulutusyksikkötyypeittäin. Oleellisen poikkeaman muodosti yksityinen aikuiskoulutussektori, jonka vastausprosentti jäi alle puoleen kokonaisvastausprosentista. Valtion budjettimäärärahojen osalta ei täysin kattavaan selvitykseen ollut mahdollista päästä aikuiskoulutukseen kohdennetun määrärahan määrittelyongelmien ja tilinpitojärjestelmän puutteiden vuoksi. Määrärahaselvityksen perusmateriaalina käytettiin valtion tulo- ja menoarvioita ky- 
seisiltä vuosilta.

Kyselylomakkeen postituksesta ja käsittelystä vastasi Otantatutkimus Oy, joka sai perusraporttinsa valmiiksi yli vuoden työskentelyn jälkeen vuoden 1983 alkuun mennessä. Perusraportin aineiston vaatimat tarkistuslaskelmat ja loppuraportin kokoaminen voitiin suorittaa tämän jälkeen. Seuraavassa esitettävät tiedot ovat yhtäältä arvioita aikuiskoulutuksen käytössä olevista kokonaisvoimavaroista, toisaalta vastausmateriaalin pohjalta tehtyjä voimavarojen laatua koskevia johtopäätöksiä.

\section{Aikuiskoulutuksen henkilöstö}

Kyselyyn vastanneiden aikuiskoulutusyksi- köiden henkilöstön kokonaismääräksi (päätoiminen, osapäivätoiminen ja sivutoiminen henkilöstö sekä luennoitsijat) saatiin yli 53000 . Aikuiskoulutuksen piirissä työskentelevän henkilöstön kokonaisarvioon päädyttiin ekstrapoloimalla saadut tiedot 964:n aikuiskoulutusyksikön mukaan. Tällöin aikuiskoulutuksen koko henkilöstön määräksi arvioitiin lähes 98000 (taulukko 1).

Suurimmat henkilöstöryhmät olivat varsinainen opetushenkilöstö ja luennoitsijat, joiden osuus kaikkiaan oli $83 \%$ koko henkilöstöstä. Silmiinpistävää aikuiskoulutuksen henkilöstössä oli sen sivutoimisuus. Päätoimisessa palveluksessa oli vajaa viidennes henkilöstöstä

Taulukko 1. Aikuiskoulutuksen henkilöstö

\begin{tabular}{|c|c|c|c|c|c|c|c|c|c|c|}
\hline \multicolumn{11}{|c|}{ Pàlvelussuhteen luonne } \\
\hline \multirow[t]{2}{*}{ Henkilöstöryhmä } & \multicolumn{2}{|c|}{$\begin{array}{c}\text { Pää- } \\
\text { toiminen }\end{array}$} & \multicolumn{2}{|c|}{$\begin{array}{l}\text { Osapäivä- } \\
\text { toiminen }\end{array}$} & \multicolumn{2}{|c|}{$\begin{array}{l}\text { Sivu- } \\
\text { toiminen }\end{array}$} & \multicolumn{2}{|c|}{ Muu } & \multicolumn{2}{|c|}{ Yhteensä } \\
\hline & & & & & & $\%$ & & $\%$ & $\mathrm{n}$ & $\%$ \\
\hline $\begin{array}{l}\text { Hallinto-organisointi- } \\
\text { ja suunnitteluhenkilöstö } \\
\text { Varsinainen opetus- }\end{array}$ & 1700 & 63 & 100 & 4 & 900 & 33 & - & - & 2700 & 100 \\
\hline henkilöstö & 9400 & 22 & 1100 & 3 & 31400 & 75 & - & - & 41900 & 100 \\
\hline $\begin{array}{l}\text { Toimistohenkilöstö } \\
\text { Kiinteistö- ja keittiö- }\end{array}$ & 2200 & 82 & 300 & 11 & 200 & 7 & - & - & 2700 & 100 \\
\hline henkilöstö & 3300 & 52 & 400 & 6 & 2700 & 42 & - & - & 6400 & 100 \\
\hline Muu henkilöstö & 1000 & 19 & 300 & 6 & 3900 & 75 & - & - & 97800 & 100 \\
\hline Luennoitsijat & - & - & - & - & - & - & 38900 & 100 & 38900 & 100 \\
\hline Yhteensä & 17600 & 18 & 2200 & 2 & 39100 & 40 & 38900 & 40 & 97800 & 100 \\
\hline
\end{tabular}

ja mikäli luennoitsijat jätetään huomiotta, nousi päätoimisten osuus lähes kolmannekseen. Eniten päätoimisia oli toimistohenkilöstössä sekä hallinto-, organisointi- ja suunnitteluhenkilöstössä. Varsinaisesta opetushenkilöstöstä $75 \%$ oli sivutoimista.

Hallinto-, organisointi- ja suunnitteluhenkilöstön sekä toimistohenkilöstön osuus koko henkilöstöstä ei merkittävästi vaihdellut eri aikuiskoulutusyksikkötyypeissä. Varsinaisen opetushenkilöstön määrässä sen sijaan oli enemmän vaihtelua. Enemmän kuin puolet koko henkilöstöstä oli varsinaista opetushenkilöstöä ammatillisissa kurssikeskuksissa, kansalais- ja työväenopistoissa, kirjeopistoissa sekä valtion, kuntien ja kirkon henkilöstökoulutuslaitoksissa. Luennoitsijoita suhteessa koko henkilöstöönsä käyttivät eniten ammattialajärjestöjen koulutuslaitokset, kesäyliopistot, liikealan erikoisoppilaitokset ja opintokeskukset. Päätoimisen hallinto-, organisointi- ja suunnitteluhenkilöstön osuudet koko henkilöstöstä eivät eri aikuiskoulutusyksikkötyy- peissä olennaisesti poikenneet toisistaan. Varsinaisessa opetushenkilöstössä poikkeamat olivat suuremmat. Pienin päätoimisen opetushenkilöstön osuus suhteessa koko opetushenkilöstöönsä oli kansalais- ja työväenopistoissa (noin 2\%).

Verrattaessa päätoimisen, osapäivätoimisen ja sivutoimisen opetushenkilöstön sekä luennoitsijoiden osuutta opetus- ja luentotunneista toisiinsa arvioitiin päätoimisen henkilöstön vastaavan lähes $2 / 3$ :sta opetus- ja luentotunteja. Sivutoimisen opetushenkilöstön osuudeksi opetus- ja luentotunneista jäi 1/4. Vähäisin päätoimisen henkilöstön osuus opetus- ja luentotunneista oli kansalais- ja työväenopistoissa ja kesäyliopistoissa. Suurin se oli ammatillisissa kurssikeskuksissa.

Vastanneiden aikuiskoulutusyksiköiden päätoimisen hallinto-, organisointi-, suunnitteluja opetushenkilöstön yleisin tutkinto oli alempi keskiasteen tutkinto tai ylempi kandidaattiasteen tutkinto. Joka toisella oli jompikumpi näistä tutkinnoista. Tutkijakoulutuksen saaneiden osuus oli vähäinen (taulukko 2). 
Taulukko 2. Aikuiskoulutuksen päätoimisen hallinto-, organisointi-, suunnittelu- ja opetushenkilöstön koulutus

Koulutusaste

Päätoiminen henkilöstö

Perusasteen tutkinto

$\mathrm{n}$

429

688

1314

629

645

1169

tutkinto

Tutkijakoulutus tai

vastaava

Koulutusaste tuntematon

Yhteensä

Koulutetuinta mainittu henkilöstö oli iltaoppikouluissa, joissa lähes kaikilla oli kandidaattiasteen koulutus. Kesäyliopistoissa, kansanopistoissa sekä kansalais- ja työväenopistoissa kandidaattiasteen koulutus oli 2/3:1la kyseisestä henkilöstöstä. Perus- ja keskiasteen suorittaneita oli mainituista henkilöistä eniten yksityisten työnantajain koulutuslaitoksissa, ammatillisissa kurssikeskuksissa, ammatillisten oppilaitosten aikuiskoulutuksessa sekä valtion, kuntien ja kirkon henkilöstökoulutuslaitoksissa.

Tiedot suoritetuista aikuiskasvatuksen tai kasvatustieteen opinnoista saatiin lähes $2 / 3$ :n osalta mainitusta henkilöstöstä. Yleisin arvo- sana oli aikuiskoulutuksen tai kasvatustieteen approbatur-arvosana, joka oli yli puolella. Korkeampia arvosanoja (laudatur tai cum laude approbatur) oli 14\%:lla. Opetushenkilöstössä korkeampia arvosanoja suorittaneiden osuus oli $10 \%$. Vastaava osuus hallinto-, organisointi- ja suunnitteluhenkilöstössä oli huomattavasti korkeampi eli $27 \%$. Suhteessa koko päätoimiseen hallinto-, organisointi- ja suunnitteluhenkilöstöönsä oli aikuiskasvatuksen tai kasvatustieteen arvosanoja eniten kansalais- ja työväenopistoissa, iltaoppikouluissa, liikealan erikoisoppilaitoksissa sekä valtion, kuntien ja kirkon henkilöstökoulutuslaitoksissa. Opetushenkilöstössä vastaavasti eniten arvosanoja oli iltaoppikouluissa, kansalaisja työväenopistoissa, kansanopistoissa sekä urheiluopistoissa. Päätoimisen hallinto-, organisointi-, suunnittelu- ja opetushenkilöstön suorittamista arvosanoista (kasvatustiede ja aikuiskasvatus) nimenomaan aikuiskasvatuksen arvosanoja oli hieman yli kolmannes. Opetusharjoittelun oli suorittanut kolmannes mainitusta henkilöstöstä.

\section{Aikuiskoulutuksen käytössä olevat tilat}

Vastanneiden aikuiskoulutusyksiköiden käytössä olevien tilojen kokonaismääräksi (täysiaikainen ja osa-aikainen käyttö) saatiin noin 2.15 milj. neliömetriä. Käytössä olevien tilojen kokonaismääräksi ekstrapoloitiin saatujen vastausten ja arvioitujen aikuiskoulutusyksikkömäärien pohjalta noin 4.51 milj. neliömetriä (taulukko 3).

Taulukko 3. Aikuiskoulutuksen käytössä olevat tilat

Tilan käyttö

\begin{tabular}{|c|c|c|c|c|c|}
\hline \multirow{2}{*}{ Tilatyyppi } & \multicolumn{2}{|c|}{ Täysiaikainen } & Osa-aikainen & \multicolumn{2}{|c|}{ Yhteensä } \\
\hline & $1000 \mathrm{~m}^{2}$ & $\%$ & $1000 \mathrm{~m}^{2}$ & $\% 1000 \mathrm{~m}^{2}$ & $\%$ \\
\hline Opetustilat & 2422,6 & 70 & 978,1 & 953400,7 & 75 \\
\hline Hallintotilat & 152,0 & 4 & 6,8 & 1158,8 & 4 \\
\hline Asuntotilat & 498,6 & 14 & 5,4 & 1504,0 & 11 \\
\hline Muut tilat & 412,0 & 12 & 34,0 & 3446,0 & 10 \\
\hline Yhteensä & 3485,2 & 100 & 1024,3 & 1004509,5 & 100 \\
\hline
\end{tabular}

Käytössä olevista kaikista tiloista $3 / 4$ oli opetustiloja. Osa-aikaisista tiloista lähes kaikki olivat opetustiloja. Muihin tiloihin luettiin mm. varasto-, liikunta-, ruokala- ja vapaaajan tilat. Eniten osa-aikaisessa käytössä olevia opetustiloja oli kansalais- ja työväenopis- toilla. Niiden käytössä olevat osa-aikaiset opetustilat muodostivat lähes $86 \%$ kaikista aikuiskoulutuksen käytössä olevista opetustiloista.

Noin kolmannes aikuiskoulutuksen opetustiloista oli kunnan koululaitoksen tiloja. Täy- 
siaikaisessa käytössä olevista opetustiloista aikuiskoulutusyksiköt omistivat yli puolet, kaikista opetustiloistaan vajaan kolmanneksen. Opetuskäyttöön vuokrattujen tilojen osuus oli noin $21 \%$. Ulkopuolisten käyttöön korvauksetta luovutettujen, vuokrattujen tai muutoin käyttämättömänä olevien opetustilojen osuus oli kaikkiaan vähäinen eli noin 1,6\%.

Omia opetustiloja ei ollut lainkaan kesäyliopistoilla, kirjeopistoilla eikä iltaoppikouluilla sekä varsin vähän kansalais- ja työväenopistoilla. Eniten omia kaikista opetustiloistaan oli $\mathrm{mm}$. kansanopistoilla, urheiluopistoilla ja liikealan erikoisoppilaitoksilla.

Käytössä olevista opetustiloista $18,5 \%$ sijaitsi haja-asutusalueella. Näistä suurin osa eli $86 \%$ oli kansalais- ja työväenopistojen käytössä. Kansalais- ja työväenopistojen opetustiloista haja-asutusalueella sijaitsi kaikkiaan kolmannes. Kansanopistoilla ja ammatillisilla kurssikeskuksilla oli myös jossain määrin opetustiloja haja-asutusalueella.

Vastaajia pyydettiin arvioimaan käytössä olevien opetustilojen käyttöastetta päivittäin, viikoittain ja työvuosittain. Käyttämätöntä opetustilakapasiteettia näytti ajoittain olevan tarjolla (taulukko 4).

Taulukko 4. Aikuiskoulutuksen käytössä olevien opetustilojen käyttöaste keskimäärin

Käyttöaste
$\%$

Päivittäin
klo $8-12$
$12-16$
$16-$

\begin{tabular}{ll}
\hline Viikottain & \\
maanantai - perjantai & 89 \\
lauantai - sunnuntai & 26 \\
\hline
\end{tabular}

\section{Työvuosittain}

tammikuu - toukokuu $\quad 78$

kesäkuu - heinäkuu 33

elokuu — joulukuu

33
76

Opetustiloista $3 / 5$ oli päivittäin käytössä. Käyttöaste ei juuri päivän eri aikoina vaihdellut. Viikonloppuisin opetustilakapasiteetista oli vapaana lähes $3 / 4$. Työvuosittain tarkasteltuna oli 3/4 kapasiteetista käytössä kesä- ja heinäkuuta lukuunottamatta. Päivisin löytyi vapaata opetustilakapasiteettia kansalais- ja työväenopistoissa, iltaisin puolestaan kansanopistoissa, ammatillisissa oppilaitoksissa ja kurssikeskuksissa sekä yksityisten työnantajien koulutuslaitoksissa. Viikonloppuisin oli lähes kaikisssa aikuiskoulutusyksikkötyypeissä käyttämätöntä opetustilakapasiteettia, eniten kuitenkin yksityisten työnantajien koulutuslaitoksissa, liikealan erikoisoppilaitoksissa sekä valtion, kuntien ja kirkon henkilöstökoulutuslaitoksissa.

Aikuiskoulutusyksiköistä $70 \%$ oli valmis lisäämään oppilasmääriään ja lähes $70 \%$ opetus- ja luentotuntejaan. Eniten valmiutta oppilasmäärien tai opetuksen lisäämiseen oli iltaoppikouluilla, kesäyliopistoilla, ammatillisilla oppilaitoksilla sekä kansalais- ja työväenopistoilla. Oppilasmääriä tai opetus- ja luentotunteja oltiin yleensä valmiita lisäämään enemmän kuin 1/3:lla aiemmista määristä. Painavimmat syyt siihen, ettei näitä haluttu lisätä, olivat joko tilojen täysaikainen käyttö, luokka- tai työnopetustilojen puute, tilojen epäkäytännöllisyys, asuntolapaikkojen puute tai vähäinen tarve opetuksen lisäämiseen. Suurimmassa ryhmässä, kansalais- ja työväenopistoissa, arvioitiin merkittävimmiksi esteiksi opetuksen lisäämiseen tilojen epäkäytännöllisyys tai niiden sopimaton sijainti sekä opetushenkilöstön puute.

\section{Aikuiskoulutuksen käytössä oleva välineistö}

Vastaajilta pyydettiin tiedot toimisto- ja opetusvälineistön määrästä, omistuspohjasta ja optimitarpeesta. Lisäksi tiedusteltiin halukkuutta luovuttaa opetusvälineistöä yksikön ulkopuolisten kouluttajan käyttöön.

Suurin osa toimistovälineistöstä oli tavanomaista (kirjoitus-, lasku- ja monistuskoneita). Vain vähäinen osa, noin $6 \%$ tästä edusti kehittyneempää toimistotekniikkaa (lajittelulaitteita, sanojenkäsittelylaitteita, pientietokoneita ja -päätteitä jne). Toimistovälineistöstä 4/5 oli aikuiskoulutusyksiköiden omaa ja $11 \%$ kunnan omistamaa. Kehittyneemmästä toimistovälineistöstä oman välineistön osuus jäi alle puoleen. Vastaavasti kunnan omistaman välineistön osuus kohosi enemmän kuin 1/3:een. Vuokratun ja jonkin muun kanssa yhteisen välineistön osuus oli vajaa viidennes. Suurin lisäystarve lähes kaikilla aikuiskoulutusyksikkötyypeillä kohdistui nimenomaan kehittyneempään toimistovälineistöön.

Myös opetusvälineistön pääosan muodostivat tavanomaiset välineet (opetusheijastimet, diaheittimet, nauhurit, televisiot ym). Opetusvälineistöstä noin $7 \%$ oli kehittyneempää tekniikkaa (tietokoneita, kuvanauhureita, automaattisesti ohjattuja laitteita, atk-pohjaisia opetusvälineitä ym). Aikuiskoulutusyksiköi- 
den omistuksessa oli $3 / 5$ välineistöstä, kunnan omistamaa oli 1/3. Opetusvälineistönkin osalta suurin lisäystarve kohdistui teknisesti kehittyneempään välineistöön. Kielistudioiden ja oppilaskirjastojen kehittämiseen tunnettiin myös tarvetta. Suurimman tarpeen opetusvälineistön lisäämiseksi ilmaisivat invalidien ja aistivikaisten ammattikoulut, kansanopistot ja opintokeskukset.

Enemmän kuin puolet aikuiskoulutusyksiköistä oli valmiita luovuttamaan kaikkia käytössään olevia opetusvälineitä tarvittaessa ulkopuolisille tai ainakin harkitsemaan tätä. Kielteisesti tai varauksellisesti lainaamiseen suhtautuivat aikuiskoulutusyksiköt vain eräiden teknisesti kehittyneempien opetusvälineiden osalta. Suopeimmin välineiden lainaamiseen ulkopuolisille suhtautuivat konekirjoituskoulut, kesäyliopistot, liikealan erikoisoppilaitokset, opintokeskukset, urheiluopistot, kansanopistot sekä kansalais- ja työväenopistot. Näiden käytössä oli kaikkiaan $63 \%$ opetusvälineistöstä. Kielteisimmin tai varauksellisimmin puolestaan suhtautuivat kirjeopistot, ammattialajärjestöjen koulutuslaitokset, yksityisten työnantajien koulutuslaitokset, iltaoppikoulut, ammatilliset oppilaitokset sekä valtion, kuntien ja kirkon henkilöstökoulutuslaitokset.

\section{Voimavarojen käyttöön liittyvät ongelmat}

Vastaajien arvioitaviksi esitettiin 15 eri ongelmaryhmää. Nämä voitiin ryhmitellä viiteen

Taulukko 5. Voimavarojen käyttöä eniten estävät ongelmat (erittäin paljon tai paljon)

Ongelma tai este

Osuus vastaajista

Etäisyystekijöistä johtuvat ongelmat (mm. tilojen sijainti)

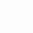

Henkilöstön palvelussuhteen huonommuus muihin koulutusmuotoihin verrattuna

Tilojen soveltumattomuus aikuiskoulutukseen

Tiedon puute tulevasta koulutustarpeesta

Puutteellinen tieto aikuiskoulutuksen tulevasta asemasta

Yhteistyön puute eri koulutusmuotojen kesken

Henkilöstön puutteellinen koulutus

Tilojen omistus- ja hallintasuhteista johtuvat käyttöesteet

Yhteistyön puute eri aikuiskoulutusmuotojen kesken
43 pääryhmään: henkilöstöön, tiloihin, opetusvälineistöön, tulevaisuuden epävarmuuteen sekä yhteistyöhön liittyviin ongelmiin ja esteisiin.

Esitettyjen ongelmaryhmien (15) saamat prosenttiarvot vaihtelivat $13 \%$ :sta $49 \%$ :iin. Edellä yhdeksän suurimman prosenttiarvon saanutta ongelmaryhmää (taulukko 5).

Lähes puolet vastaajista katsoi etäisyystekijöiden vaikuttavan merkittävästi voimavarojen käyttöön. Keskeisinä ongelmina pidettiin myös henkilöstön palvelussuhteen ehtojen huonommuutta muihin koulutusmuotoihin verrattuna, tilojen soveltumattomuutta aikuiskoulutukseen sekä tiedon puutetta tulevasta koulutustarpeesta. Vähiten ongelmia katsottiin liittyvän opetusvälineiden käyttöön, sillä vähemmän kuin neljännes vastaajista kiinnitti huomiota opetusvälineisiin liittyviin ongelmiin.

Henkilöstöön liittyviä ongelmia (esim. palkkauksen huonommuutta tai henkilöstön joustavan käytön esteitä eri koulutusmuotojen kesken) korostivat kansalais- ja työväenopistot, kesäyliopistot, ammatilliset kurssikeskukset sekä invalidien ja aistivikaisten ammattikoulut. Tiloihin liittyviä ongelmia (esim. tilojen soveltumattomuutta aikuiskoulutukseen tai tilojen omistussuhteista johtuvia vaikeuksia) toivat esille kansalais- ja työväenopistot, kielenopetuslaitokset, liikealan erikoisoppilaitokset ja yksityisten työnantajain koulutuslaitokset. Opetusvälineiden käyttöön liittyvät ongelmat (mm. opetusvälineiden käytön tekniset ja huollolliset vaikeudet tai vanhanaikaisuus) askarruttivat valtion, kuntien ja kirkon henkilöstökoulutuslaitoksia, kirjeopistoja ja kielenopetuslaitoksia.

Nykyistä lainsäädäntöä pitivät voimavarojen käytön kannalta ongelmana opintokeskukset, liikealan erikoisoppilaitokset ja kirjeopistot. Yhteistyön puutetta eri koulutusmuotojen kesken sekä yhteistyötä torjuvia asenteita voimavarojen käyttöä estävinä tekijöinä valittivat mm. kesäyliopistot, ammatilliset kurssikeskukset, iltaoppikoulut, kirjeopistot ja liikealan erikoisoppilaitokset.

\section{Valtion tulo- ja menoarvion aikuiskoulutusmäärärahat}

Valtion tulo- ja menoarviossa oli aikuiskoulutukseen kohdennettuja määrärahoja kaikkien ministeriöiden budjettimomenteilla, eniten opetusministeriön pääluokassa. Monen ministeriön kohdalla aikuiskoulutukseen kohdennettujen määrärahojen arviointi osoittautui ongelmalliseksi toisaalta itse aikuiskoulutukseen kohdennetun määrärahan määrittele- 
misen, toisaalta tilinpitojärjestelmän puutteiden vuoksi.

Valtion tulo- ja menoarviossa suunnattiin aikuiskoulutukseen vuonna 1981 kaikkiaan $\mathrm{n}$. 1,25 mrd markkaa ja vuonna 1982 n. 1,37 mrd markkaa (taulukko 6).

Taulukko 6. Valtion tulo- ja menoarviossa aikuiskoulutukseen kohdennetut määrärahat 198182

Määrärahat

\begin{tabular}{|c|c|c|c|c|}
\hline Hallinnonala/Pääluokka & & & & \\
\hline & $1000 \mathrm{mk}$ & $\%$ & $1000 \mathrm{mk}$ & $\%$ \\
\hline Valtioneuvosto & 54 & - & 56 & - \\
\hline Ulkoasiainministeriö & 411 & - & 495 & - \\
\hline Oikeusministeriö & 7807 & 0,6 & 7273 & 0,5 \\
\hline Sisäasiainministeriö & 22841 & 1,8 & 23354 & 1,7 \\
\hline Puolustusministeriö & 53090 & 4,3 & 61050 & 4,5 \\
\hline Valtiovarainministeriö & 9686 & 0,8 & 11582 & 0,8 \\
\hline Opetusministeriö & 1023667 & 82,1 & 1122471 & 82,0 \\
\hline Maa- ja metsätalousministeriö & 2538 & 0,2 & 2943 & 0,2 \\
\hline Liikenneministeriö & 109180 & 8,8 & 120350 & 8,8 \\
\hline Kauppa- ja teollisuusministeriö & 9480 & 0,8 & 12193 & 0,9 \\
\hline Sosiaali- ja terveysministeriö & 5566 & 0,4 & 6053 & 0,4 \\
\hline Työvoimaministeriö & 2300 & 0,2 & 2480 & 0,2 \\
\hline Yhteensä & 1246620 & 100,0 & 1370300 & 100,0 \\
\hline
\end{tabular}

Opetusministeriön osuus kaikista aikuiskoulutukseen kohdennetuista budjettimäärärahoista on yli 4/5. Myös liikenne- ja puolustusministeriöiden pääluokissa on huomattavia aikuiskoulutusmäärärahoja.

Mainittujen määrärahojen lisäksi tulevat sellaiset määrärahat, joiden suuruutta ei tilinpidollisista syistä ollut mahdollista arvioida. Tällaisia aikuiskoulutukseen kohdennettuja määrärahoja on opetusministeriön, oikeusministeriön, kauppa- ja teollisuusministeriön, puolustusministeriön, sosiaali- ja terveysministeriön ja valtiovarainministeriön pääluokissa.

\section{Selvityksen arviointia}

Monista selvityksen tekemiseen liittyneistä ongelmista huolimatta voitaneen sen todeta ainakin pääpiirteittäin antaneen vastaukset esitettyihin kysymyksiin voimavarojen määrästä ja laadusta. Selvitys puutteineenkin tarjonnee mahdollisuuksia jatkotyöskentelylle. Se lienee vahvistanut tai korjannut joitain ennakkokäsityksiä ja ehkä herättänyt uusia kysymyksiä selvitettäväksi.

Selvitys antoi vahvistusta sille käsitykselle, että aikuiskoulutuksen henkilöstö valtaosaltaan koostuu sivutoimisista ja luennoitsijoista. Suurin ryhmä luonnollisesti on opetushenkilöstö. Kuitenkin opetus- ja luentotunneista vastaa pääosin päätoiminen henkilöstö. Aikuiskoulutuksen henkilöstövoimavarojen käytön tehostaminen edellyttänee jatkossa lisää päätoimista henkilöstöä, joskin sivutoimisen henkilöstön lukumäärä tullee säilymään verrattain korkeana. Henkilöstövoimavarojen käytön tehostamisen kannalta on edelleen tärkeää harkita eri koulutusmuotojen keskinäistä ja aikuiskoulutuslohkojen sisäistä henkilöstön yhteiskäyttöä. Aikuiskoulutuksen erityistarpeet ja sen asema osana jatkuvaa koulutusta vaatinevat erityisesti sen henkilöstön aikuiskasvatuksen ja kasvatustieteen opintojen tehostamista.

Aikuiskoulutuksen tilat näyttävät pääosiltaan vastaavan määrällisesti niille asetettuja odotuksia. Opetustiloista haja-asutusalueella sijaitsee vain vajaa viidennes ja näistä valtaosa on kansalais- ja työväenopistojen käytössä. Etäisyystekijät muodostavat kuitenkin aikuiskoulutuksessa merkittävän ongelman. Ongelmat liittynevät niin tilojen sijaintiin kuin aikuiskoulutuspalvelujen saavutettavuuteen yleisemminkin. Yhtenä opetustilojen käyttöön liittyvänä ongelmana korostettiin tilojen soveltumattomuutta aikuiskoulutukseen. Jatkossa tulisi ilmeisesti pyrkiä yhä enemmän kehittämään aikuisille soveltuvia opiskeluympäristöjä. Sitä edellyttäisikö tämä täysin omia opetustiloja aikuisille vai nykyisten opetustilojen kehittämistä yhä "aikuismaisemmiksi", tulisi tarkoin harkita. Käyttämätöntä opetustilakapasiteettia on jossain määrin olemassa, mikä tulisi ottaa huomioon aikuiskoulutuspalvelujen lisäämistä harkittaessa.

Esiin tuli toimisto- iá opetusvälineistön määrällinen ja laadullinen riittämättömyys ai- 
nakin nykyaikaisen ja teknisesti kehittyneemmän välineistön osalta. Suurin osa aikuiskoulutuslaitoksista on valmiita lainaamaan opetusvälineistöään oman yksikkönsä ulkopuolelle. Tämäkin tarjonnee osaltaan mahdollisuuksia voimavarojen käytön tehostamiseen ja mahdollisesti aikuiskou?ztuspalvelujen lisäämiseen.

Valtion tulo- ja menoarviossa oli eri pääluokissa määrärahoja, joita kohdennetaan aikuiskoulutukseen. Yleensä määrärahojen kohdentaminen näyttää tapahtuvan lähinnä kunkin hallinnonalan sisäisten tarpeiden ja painotusten mukaan ilman koordinointia. Suurin osa määrärahoista on kuitenkin opetusministeriön hallinnonalan käytössä. Tämä takaa määrärahojen kohdentumisen aikuiskoulutuksen eri alueille verrattain tasapuolisesti ja ilman merkittäviä päällekkäisyyksiä. Näyttäisi kuitenkin perustellulta kehittää yhteistyömuotoja, joiden avulla myös opetusministeriön hallinnonalan ulkopuolella olevia aikuiskoulutusmäärärahoja voitaisiin kohdentaa aiempaa koordinoidummin aikuiskoulutuksen käyttöön. 